
Preparation Eco-Friend and Characteristic of Gold Nanoparticles by Orchid and Gum Arabic as a Reducing Agent

Dhelal A. Shabeeb, Abdulalah Th. Mohammed and Adawiya J. Haider

\title{
Preparation Eco-Friend and Characteristic of Gold Nanoparticles by Orchid and Gum Arabic as a Reducing Agent
}

\author{
Dhelal A. Shabeeb*, Abdulalah Th. Mohammed * and Adawiya J. Haider** \\ *Department of chemistry - College of science - University of Anbar - Iraq. \\ ** Department of Nanotechnology and Advanced Materials Center University of Technology- \\ Baghdad, Iraq.
}

\section{Received 25 July 2016 ; Accepted 18 September 2016}

\begin{abstract}
Eco-friendly green synthesis is one of the favorable branches of nanoscience for usage in different biomedical fields this option due to nontoxic and very low cost of synthesis. we describe the preparation of gold nanoparticles using an orchid (polysaccharide) and gum arabic as reducing agent and use new method ( inverse method) in preparation, a new easy and economical method has been developed by adding the gold ion $\left(\mathrm{Au}^{3+}\right)$ solution to the reducing agent solution with heating and stirring . Green synthesis of gold nano particle using various natural material reduces aqueous $\mathrm{HAuCl}_{4} \cdot 3 \mathrm{H}_{2} \mathrm{O}$ to $\mathrm{Au}^{\circ}$. Synthesized nano particle is confirmed by the change of color of chloroauric acid which is yellow in color, and growth of nanoparicle was monitored by surface plasmon behavior using UV-Vis Spectroscopy.The prepared gold nanoparticles was characterized by a peak at $528 \mathrm{~nm}$ for both orchid and gum Arabic, zeta potential, AFM, and detect clearly TEM images and the size of the gold nanoparticles were 14$30 \mathrm{~nm}$ for orchid and 20-50nm for gum Arabic in size. Morphology whereas TEM image shows different shapes like hexagonal, and spherical.
\end{abstract}

Key words: inverse method, gold nanoparticle, green synthesis‘ characterization, natural material 


\section{DIVALA JOURNAL FOR PURE SCIENCES}

\section{Preparation Eco-Friend and Characteristic of Gold Nanoparticles by Orchid}

and Gum Arabic as a Reducing Agent

Dhelal A. Shabeeb, Abdulalah Th. Mohammed and Adawiya J. Haider

التحضير بالطريقة الخضراء والتشخيص لمواد الذهب النانوية باستعمال الصمغ العربي والسحلب

\section{كعوامل مختزلة}

ظلال عبد الغفور شبيب* ، عبد الاله ثابت محمد * و عدوية جمعة حيدر**

"قسم الكيمياء - كلية العلوم - جامعة الانبار - العراق

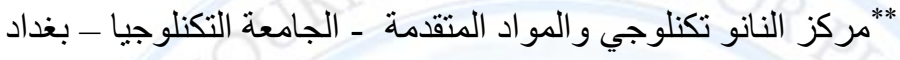

\section{الخلاصة}

التحضير بالطريقة الخضر اء او ما يسمى الصديق للبيئة هو واحد من الفروع المفضلة في علم النانو والمستخدمة في مختلف مجالات الطب الحيوي سبب هذا الاختيار لعدم سمية هذه الطريقة وكلفتها الواطئة . في بحثنا تم وصف تحضير جسيمات الذهب النانوية باستخدام كل من المواد الطبيعية السحلب وهو مادة متعددة السكريات والصمغ العربي كعو امل مختزلة . باستخدام الطريقة العكسية في التحضير أب عكس الطريقة الثائعة في التحضير وذللك لكونه اسهل و اقتصادي في التحكم

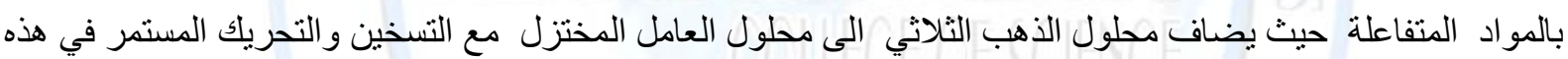
الطريقة تم استخدام مواد متنوعة لاختزال المحلول المائي لايون الذهب الثثلاثي الى عنصر الذهب جسيمات الذهب النانوية

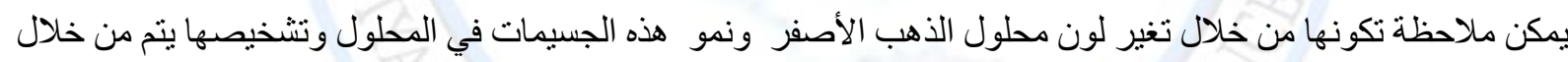

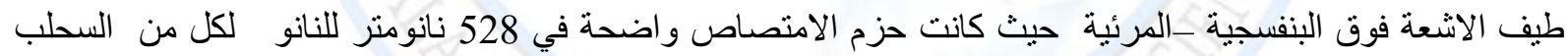
و الصمغ العربي ، جهد زيتا ، مجهر القوة الذرية والمجهر الالكتروني الناقل الذي بينت صوره حجوم مختلفة في المدى 14-30 نانومتر باستخدام السحلب والمدى 20-50 نانومتر باستخدام الصمغ العربي وكذلك اشكال مختلفة للجسيمات الذهب النانوية مثل الكروي و الثكل السداسي كلمات المفتاحية : الطريقة المعكوسة ، جسيمات النانو ذهب ، التحضير الأخضر، التتخيص، المواد الطبيعية 


\title{
Preparation Eco-Friend and Characteristic of Gold Nanoparticles by Orchid and Gum Arabic as a Reducing Agent
}

\author{
Dhelal A. Shabeeb, Abdulalah Th. Mohammed and Adawiya J. Haider
}

\section{$\underline{\text { Introduction }}$}

Nano biotechnology is one the most common branches, which received the most attention from the researchers, due to its economic and eco-friendly process to preparation particles with a dimension smaller than $100 \mathrm{~nm}$, [1]. Nanoparticles are prepared by different methods such as chemical, physical, mechanical and biological [2]. The gold nanoparticles is of special interest because of its application in catalysis, sensor, electronics, medicine, drug delivery, biomedical diagnostics, bio labeling, tissue/tumor imaging and photo thermal therapy $[3,4]$.

Preparation eco-friendly of nanoparticles by natural materials is of great interest, the major goal of this study was the preparation of AuNPs by the aqueous. Orchid is herbaceous perennial plant which grows up to $60 \mathrm{~cm}$ its narrow leaves are often stained with colored black , leg flowers are purple color and has a couple of tubers exist beneath the surface of the ground color light brown and the inside creamy yellow. These tubers contain resins, gel, protein, starch, sucrose and minerals, orchid is utilized for variety of diseases including thread in children, skin diseases; a form of tuberculosis, besides it's big value in serving as a special diet [5].Gum Arabic (GA) also known Gum Acacia is a natural gum harvested from the exterior of acacia trees in the form of dry, hard nodules about 10-50 $\mathrm{mm}$ in diameter, and ranging from almost colorless to brown. Gum Arabic has high water solubility It is a branched-chain, polysaccharide, either neutral or little acidic, found as a mixed calcium, magnesium and potassium salt of a polysaccharide acid .Gum acacia is utilized in pharmaceutical, cosmetic and food industries as an emulsifier and stabilizer, and in some countries in the traditional therapy of patients with chronic kidney disease, acacia is basically nontoxic when ingested [6]. 


\section{DIYYLA JOUURNAL FOR PURE SCIENCES}

Preparation Eco-Friend and Characteristic of Gold Nanoparticles by Orchid and Gum Arabic as a Reducing Agent

Dhelal A. Shabeeb, Abdulalah Th. Mohammed and Adawiya J. Haider

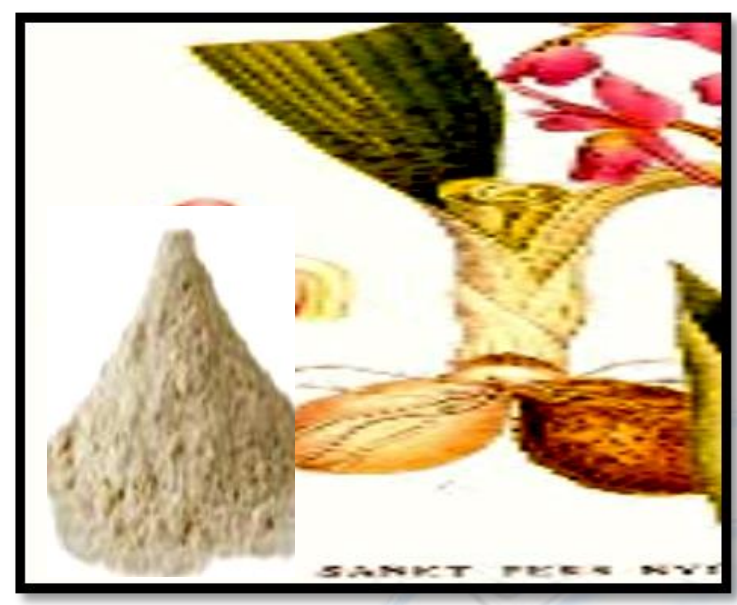

Figure 1: Form shows root of orchid.

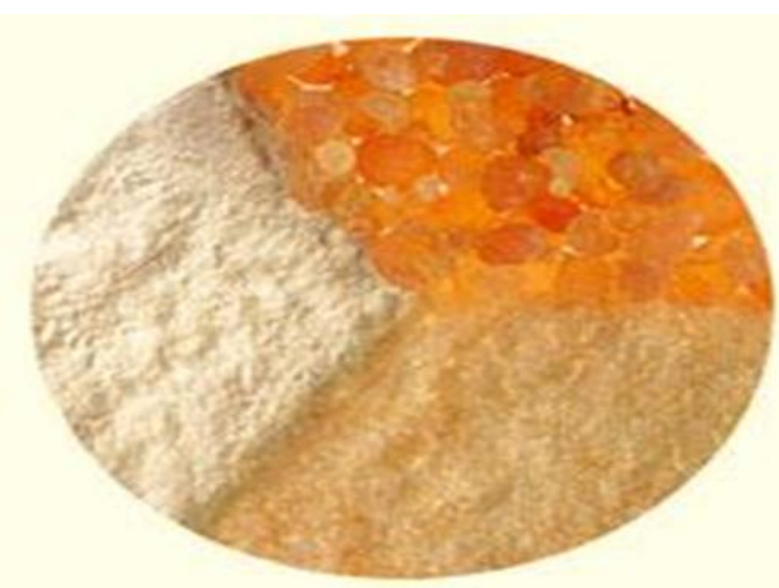

Figure 2: form of Gum Arabic

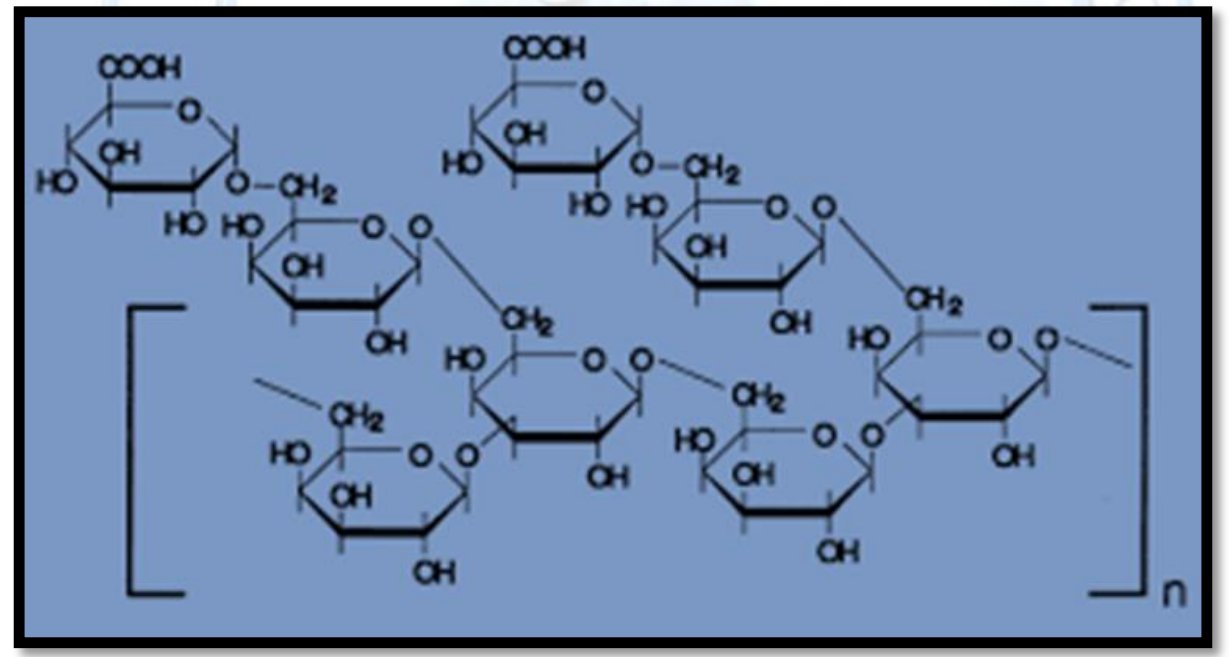

Figure 3: Structure of Gum Arabic 


\section{Preparation Eco-Friend and Characteristic of Gold Nanoparticles by Orchid and Gum Arabic as a Reducing Agent}

Dhelal A. Shabeeb, Abdulalah Th. Mohammed and Adawiya J. Haider

\section{Experimental}

\section{1- Prepare of gold nanoparticles by orchid plant as reducing agent}

$0.5 \mathrm{~g}$ of orchid was dissolved in $250 \mathrm{ml}$ distilled water the solution was heated to a temperature between $60-70 \mathrm{C}^{0}$, to this solution $3.6 \mathrm{ml}$ of $10 \mathrm{mM} \mathrm{HAuCl}_{4} .3 \mathrm{H}_{2} \mathrm{O}(99 \%$ HIMEDIA) was quickly added with stirring orchid.After $1 \mathrm{hr}$ the color of the solution was changed from pale yellow to deep red. This indicates the formation of GNPs. Of the same method in prepared $\mathrm{GNP}_{\mathrm{S}}$ by using gum arabic

\section{Characterization of gold nanoparticles.}

$\mathrm{GNP}_{\mathrm{s}}$ were characterized by UV-Vis spectroscopy (Shimadzu, Japan), Zeta potential analyzer (Brook haven, USA), Atomic force microscope (AFM), (SPM AA 3000, USA), Transmission electron microscope (TEM), (Philips CM 100, Holland).

\section{Results and discussion.}

\section{1-Visual and UV-Vis spectrum study.}

The optical color variation from yellow to red after treatment of $\mathrm{Au}^{+3}$ with orchid and gum Arabic the preparation of AuNPs by reduction of $\mathrm{Au}^{+3}$ to $\mathrm{Au}$. This variation in solution color may be refer to the surface plasmon resonance (SPR), a particular phenomenon which appear due to the collective oscillations of electrons in the conduction band with that of electromagnetic radiation owing to which it gives absorption in the UV-Vis region [7].The time-dependent appearance of two new absorption peaks at $\lambda$ max $=528 \mathrm{~nm}$ for both orchid and gum Arabic. The change in the position of these bands gives information about the particle size, morphology, and adsorbed kind on the surface [8, 9, 10, 11]. 


\section{DIYALA JOURNAL FOR PURE SCIENCES}

Preparation Eco-Friend and Characteristic of Gold Nanoparticles by Orchid and Gum Arabic as a Reducing Agent

Dhelal A. Shabeeb, Abdulalah Th. Mohammed and Adawiya J. Haider

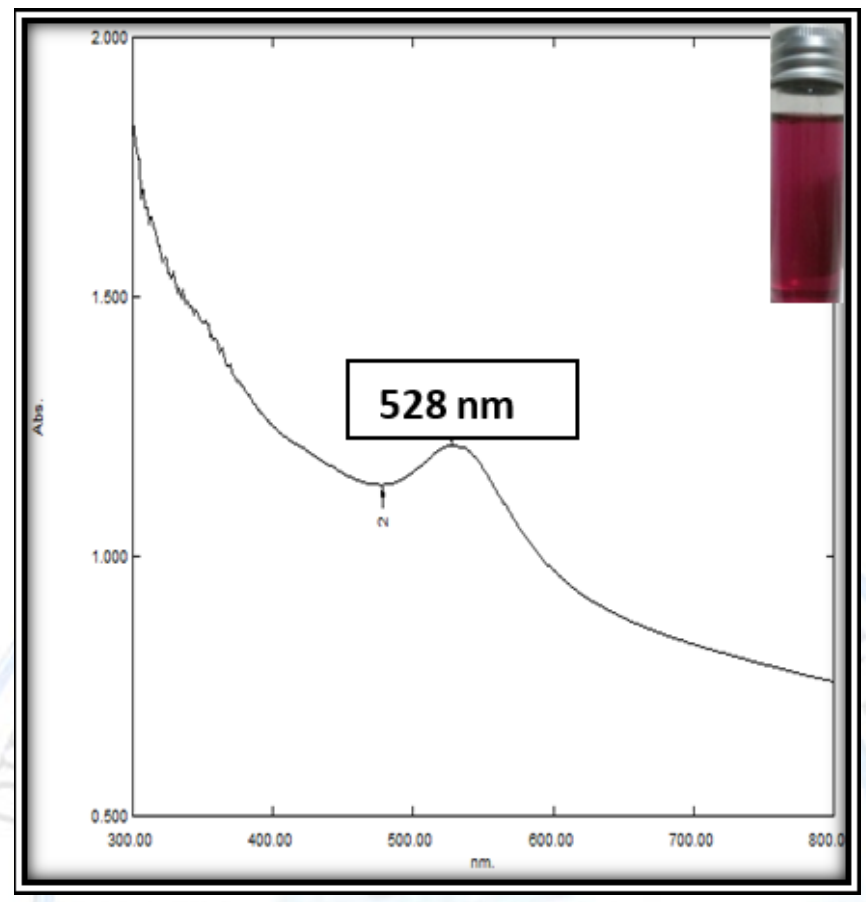

Figure 4: UV-Vis absorption spectrum GNPs using orchid as reducing agent

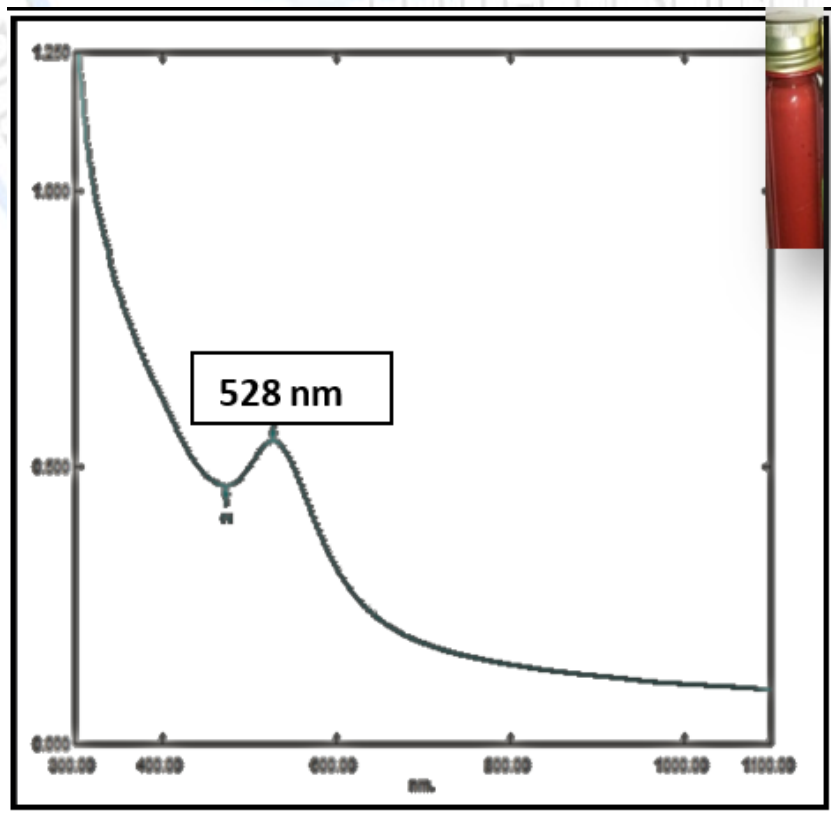

Figure 5: UV-Vis absorption spectrum of GNPs of using gum Arabic as reducing agent 


\section{Preparation Eco-Friend and Characteristic of Gold Nanoparticles by Orchid and Gum Arabic as a Reducing Agent}

\section{Dhelal A. Shabeeb, Abdulalah Th. Mohammed and Adawiya J. Haider}

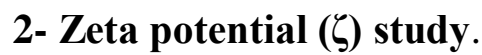

Zeta potential, the zeta potential is a key indicator of the stability of colloidal dispersions. The volume of the zeta potential indicates the degree of electrostatic repulsion between adjacent, similarly charged particles in a dispersion. For molecules and particles that are small enough, a high zeta potential will confer stability, the solution or dispersion will resist aggregation. When the potential is small, attractive forces may exceed this repulsion and the dispersion may break and flocculate, gold nanoparticle consider stable when their zeta potential are more positive than $+30 \mathrm{mV}$ or more negative than $-30 \mathrm{mV}$.[12] zeta potential for Au NPs utilized orchid reducing agent was $-14 \mathrm{mV}$ was unstable for a long time while utilized gum Arabic as reducing agent was $-23.18 \mathrm{mV}$ was stable for long time keeping at room temperature

\section{3- AFM study}

The atomic force microscope (AFM) is suitable for properties nanoparticles. It show the ability of $3 \mathrm{D}$ visualization and both qualitative and quantitative information on many physical properties including size, morphology, surface texture and roughness. Statistical information, including size, surface area, and volume distributions, can be specific as well. A wide range of particle sizes can be describe in the same scan, from 1 nanometer to 8 micrometers. As well as, the AFM utilized describe nanoparticles in double mediums including ambient air, controlled environments, and even liquid dispersions. [13] GNPS for orchid as reducing agent have a roughness surface and big particles diameter distribution, the range particle of GNPs was measured by AFM images was $(68 \mathrm{~nm})$ but GNPs for gum Arabic as reducing agent have a smooth surface and small particles diameter distribution. The range particle of GNPs was measured by AFM images was $53 \mathrm{~nm}$ figure 6,7 shown that. 


\section{DIVALA JOURNAL FOR PURE SCIENCES}

Preparation Eco-Friend and Characteristic of Gold Nanoparticles by Orchid and Gum Arabic as a Reducing Agent

Dhelal A. Shabeeb, Abdulalah Th. Mohammed and Adawiya J. Haider

A

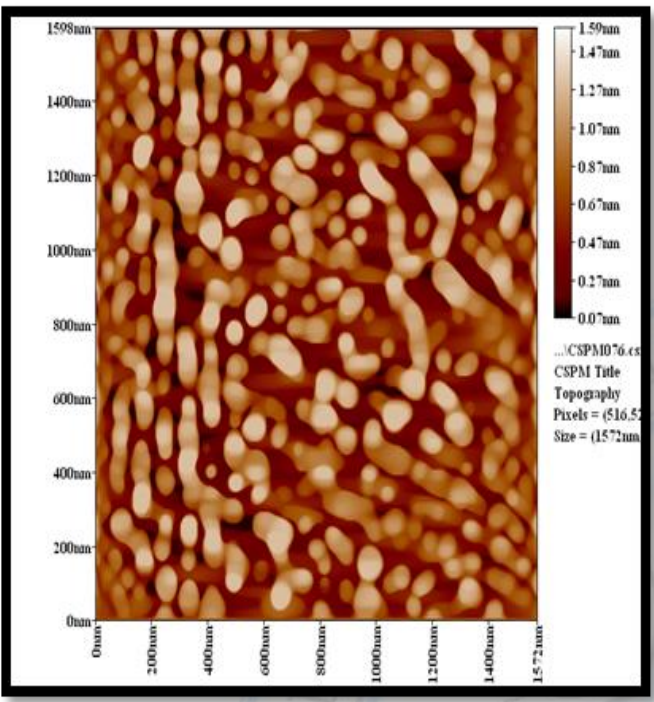

B

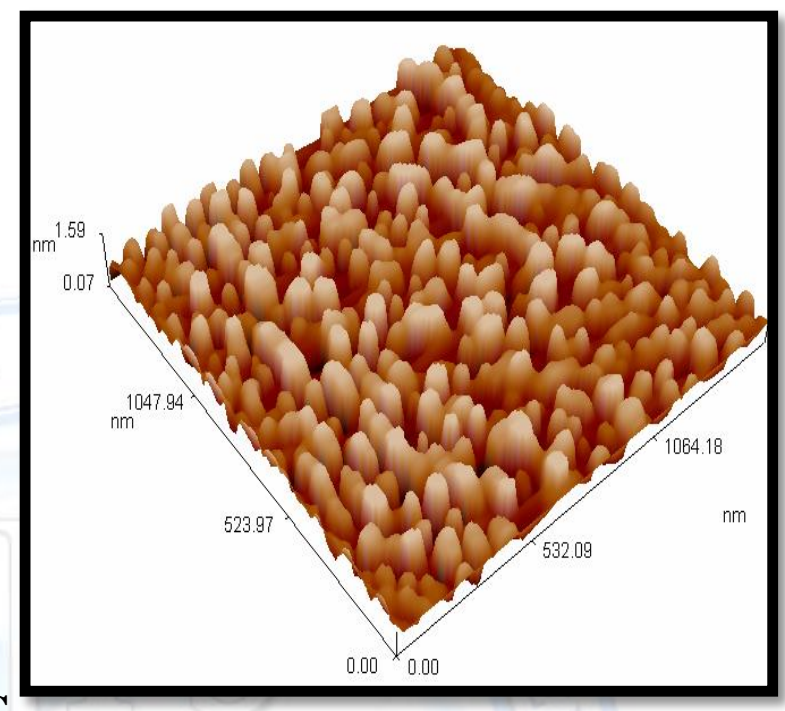

C

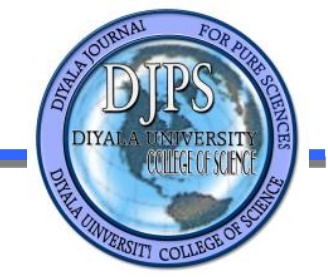




\section{DIVALA JOURNAL FOR PURE SCIENCES}

Preparation Eco-Friend and Characteristic of Gold Nanoparticles by Orchid and Gum Arabic as a Reducing Agent

Dhelal A. Shabeeb, Abdulalah Th. Mohammed and Adawiya J. Haider

A
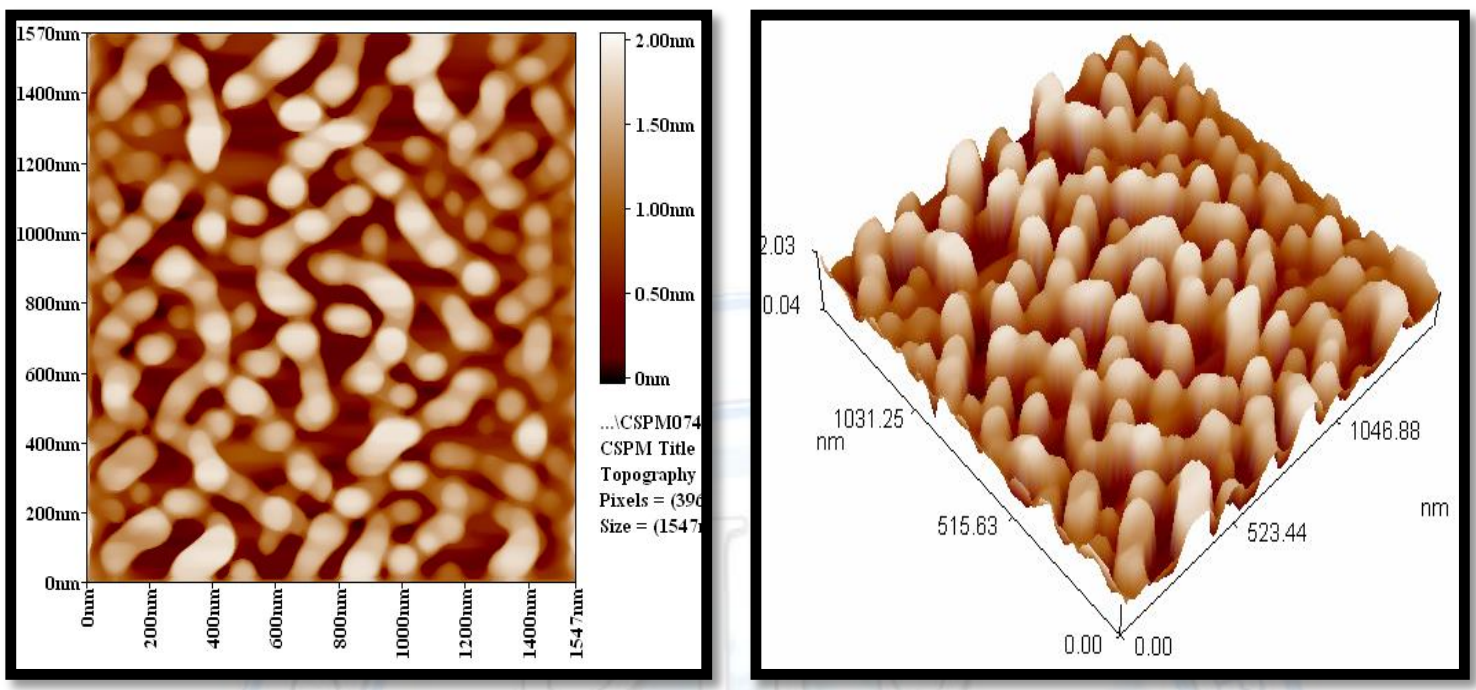

C

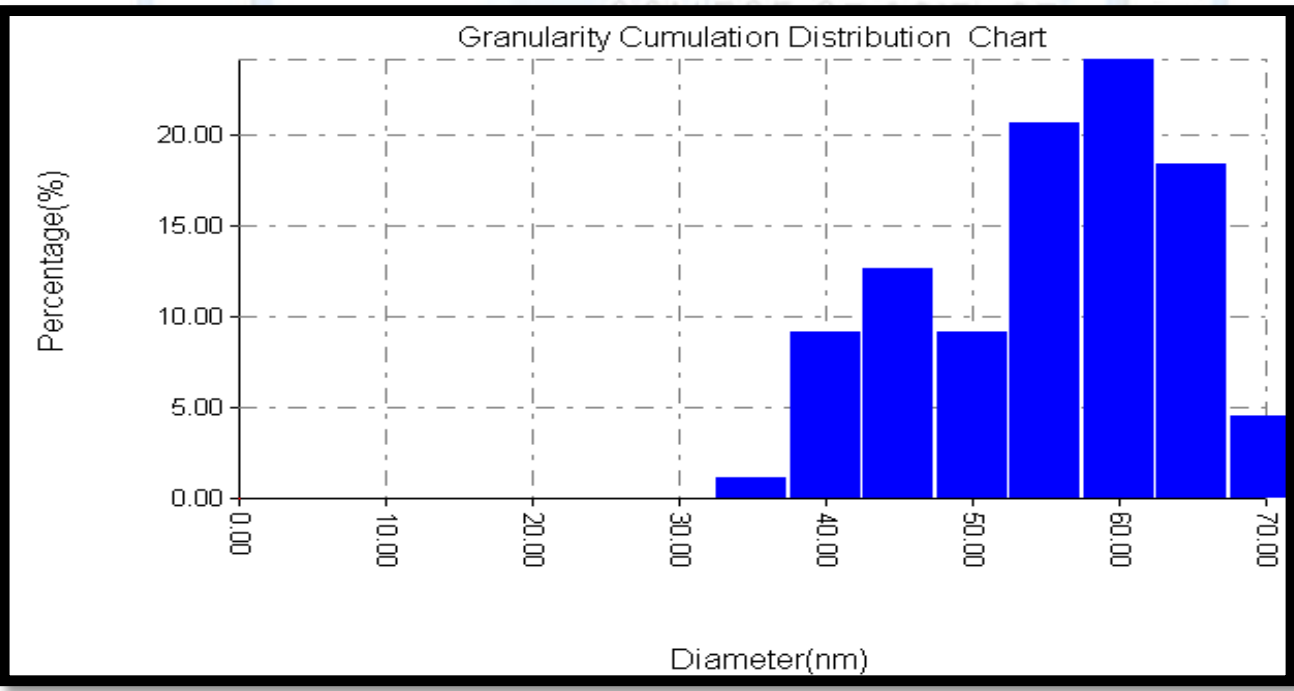

Figure 7: AFM image of $\mathrm{GNP}_{\mathrm{s}}(\mathrm{A})$ 2D, (B) 3D, (C) average particles diameter 53nm for GNPs by using gum Arabic as reducing agent 


\section{DIYALA JOURNAL FOR PURE SCIENCES}

\section{Preparation Eco-Friend and Characteristic of Gold Nanoparticles by Orchid}

and Gum Arabic as a Reducing Agent

Dhelal A. Shabeeb, Abdulalah Th. Mohammed and Adawiya J. Haider

\section{4- TEM study}

The morphology, size and crystallinity of the as-synthesized AuNPs were inspected by TEM measurement. Figures $(8,9)$ display TEM images of AuNPs prepared by orchid and gum Arabic respectively. This research indicates the formation of spherical and other shapes of particles in diameter in the range of $14-50 \mathrm{~nm}$, this result that was constant with $\mathrm{UV}-\mathrm{V}$ is analysis. The hexagonal shape in gum Arabic (Figure 9), and spherical shape in orchid reducing agent (Figure 8).
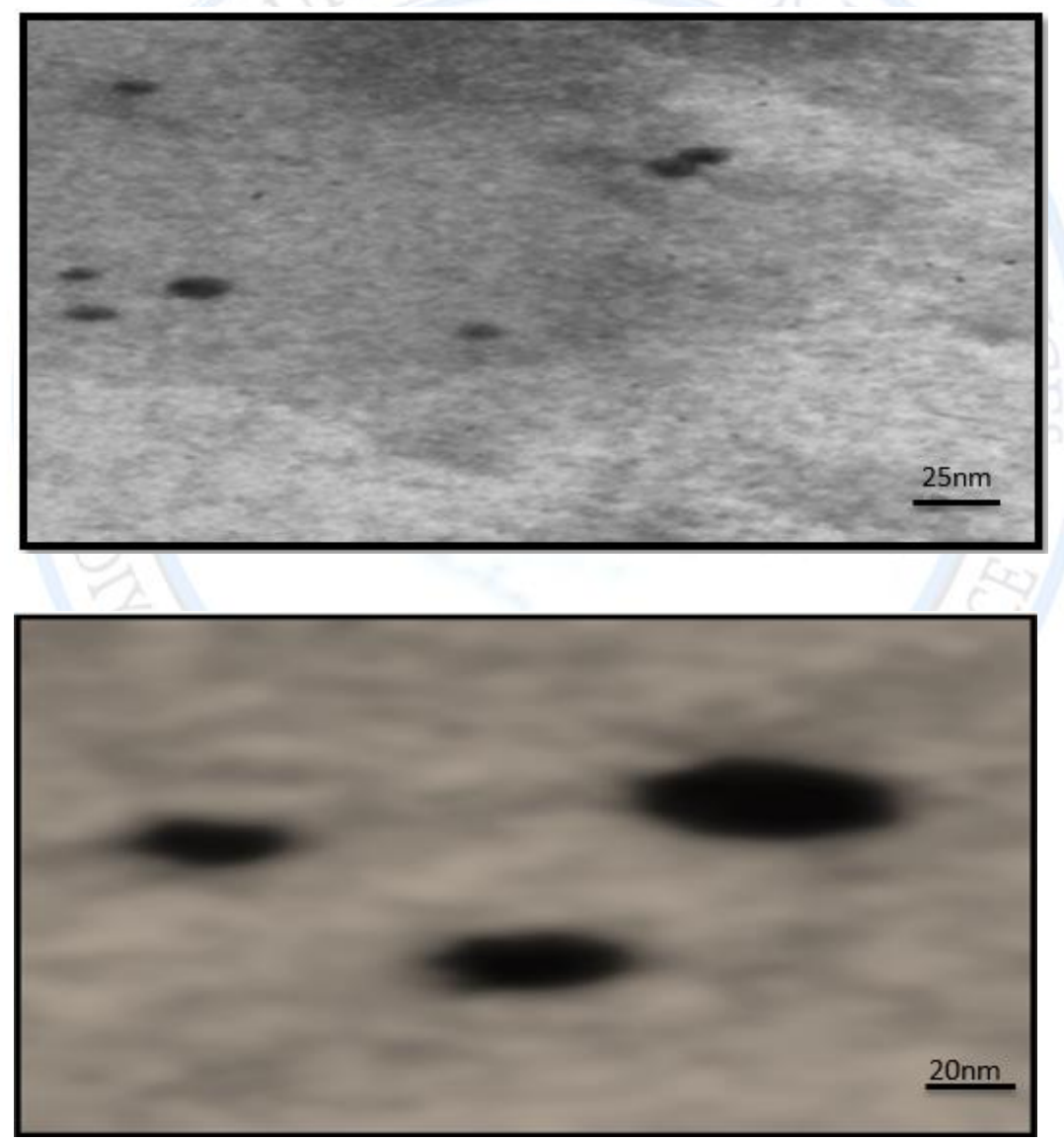

Figure 8: TEM image of GNPS using orchid as reducing agent resulting particle size 14, $18 \mathrm{~nm}$ (low and high magnification). 


\section{DIYALA JOURNAL FOR PURE SCIENCES}

Preparation Eco-Friend and Characteristic of Gold Nanoparticles by Orchid and Gum Arabic as a Reducing Agent

Dhelal A. Shabeeb, Abdulalah Th. Mohammed and Adawiya J. Haider
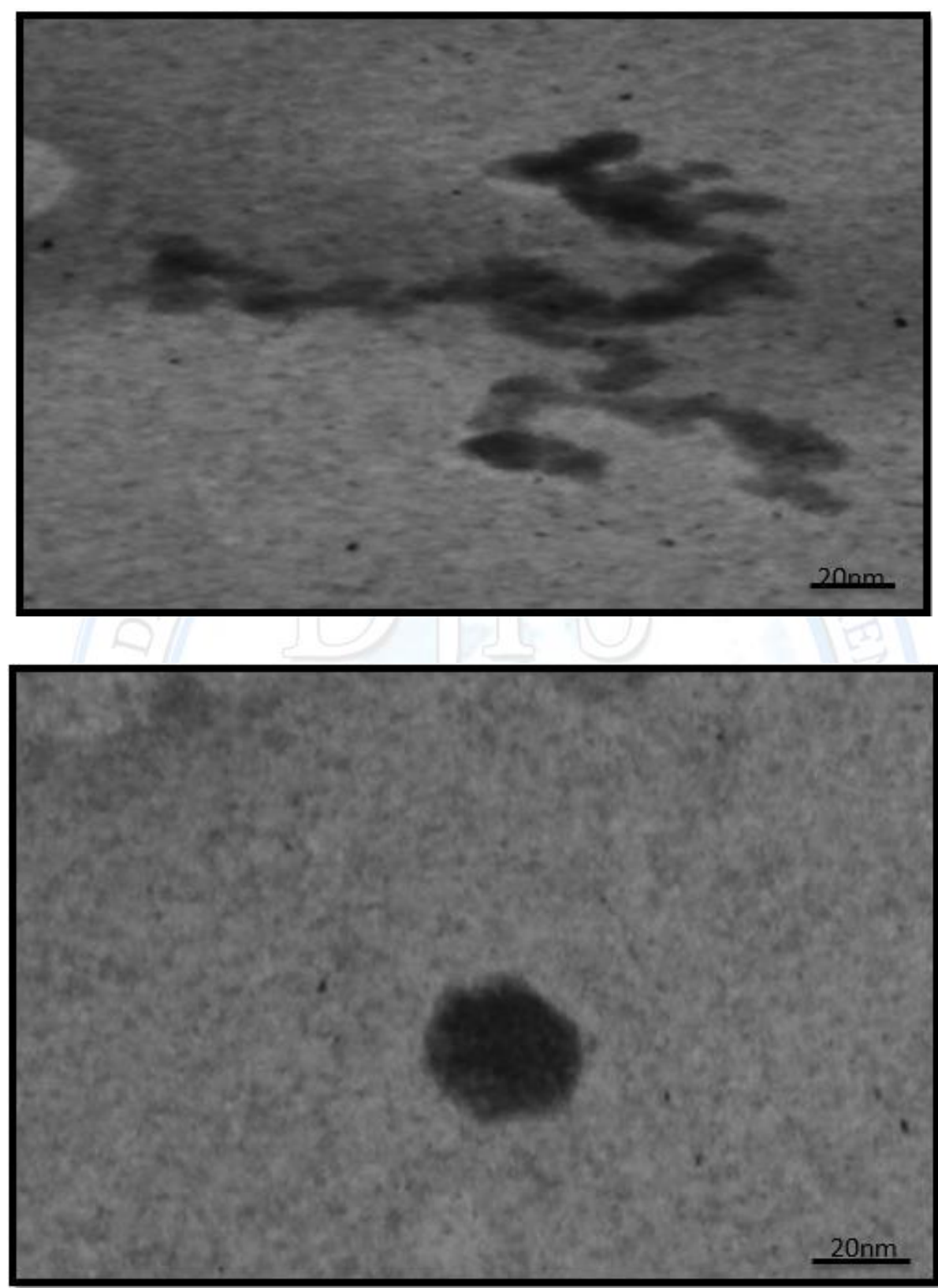

Figure 9: TEM image of GNPS using gum Arabic as reducing agent resulting particle size between 20- $50 \mathrm{~nm}$ 


\section{Preparation Eco-Friend and Characteristic of Gold Nanoparticles by Orchid and Gum Arabic as a Reducing Agent}

\section{Dhelal A. Shabeeb, Abdulalah Th. Mohammed and Adawiya J. Haider}

TEM is the one of the most popular characterization techniques for nanoparticles. [14] In this technique, a real image of nanoparticles is taken, different magnifications can be used to see a more detailed or general shape of nanoparticles. These images contain a lot of information regarding shape and size distribution, and even crystallographic structure and characteristics of nanoparticles [15].TEM images information shows that structure and kind of reducing agent play an important role to reduce the $\mathrm{HAuCl}_{4} \cdot 3 \mathrm{H}_{2} \mathrm{O}$ into gold nano composites of various morphology, this process supply highly stable. GNPs use gum Arabic as reducing agent the size of the nanoparticle $44 \mathrm{~nm}$. Shape differently particles formats (clusters, spherical, branched chain) average size between $(20$ - 50) $\mathrm{nm}$. Among the forms there was a hexagonal crystal. Using different reducing agents not only as a shape control but also as promoting formation of Au nano crystals for the synthesis and shape modulation of the highly pure Au nanostructure in high yield.

\section{$\underline{\text { Conclusion }}$}

This paper describes the facile and rabid synthesis of gold nanoparticles by a novel biochemical route. The new method (reverse method) was used by adding the $\mathrm{Au}^{3+}$ solution to the reducing agent with heating and stirring. The advantages of the reverse method are Simple and easy method which can be done by undergraduate and graduate students. Control of the used amount of gold salt and the reducing agent and also an easy way to follow-up the gold nano-particles formation through the red color of solution In conclusion, we have inspected the use of orchid and gum Arabic as a reducing and stabilizing agent for the prepare of AuNPs in an water middle. The UV-Vis ,zeta potential, AFM and TEM results display that as prepared Au NPs are poly disperse nature, quasi-spherical and hexagonal form with an median size from $14-$ $95 \mathrm{~nm}$.

Acknowledgment :The authors wish to thank Dr.TahaShawi , engineer: Hemin R. Abdul rahman , and Miss Muneera K. Ahmed for performing the UV-Vis , AFM , TEM measurements 
Preparation Eco-Friend and Characteristic of Gold Nanoparticles by Orchid and Gum Arabic as a Reducing Agent

Dhelal A. Shabeeb, Abdulalah Th. Mohammed and Adawiya J. Haider

\section{$\underline{\text { References }}$}

1. Ahmad A, Mukherjee P, Senapati S, Mandal D, Khan MI, et al . " Extracellular biosynthesis of silver nanoparticles using the fungus Fusarium oxysporum ". Colloids Surfaces, B: Bio interfaces. (2003) 27: 313-318.

2. Jain. PK, Huang. X, El-Sayed IH, El-Sayed. MA “ Noble metals on the nanoscale: optical and photothermal properties and some applications in imaging, sensing, biology, and medicine ". Acc Chem Res . (2008) 41: 1578-1586.

3. Dykman. L, Khlebtsov. N "Gold nanoparticles in biomedical applications: recent advances and perspectives”. Chem Soc Rev . (2012) 41: 2256-2282.

4. Kumar. B, Smita. K, Seqqat. R, Benalcazar. K, Grijalva. M "In vitro evaluation of silver nanoparticles cytotoxicity on Hepatic cancer (Hep-G2) cell line and their antioxidant activity: Green approach for fabrication and application ". Journal of Photochemistry \& Photobiology, B: Biology . (2016) 159: 8-13.

5. Jacquemyn. H, Brys. R, Honnay.O and Hutchings. M "Biological Flora of the British Isles: Orchismascula (L.) L." Journal of Ecology. (2009) 97(252): 360-377.

6. Azzaoui. K, Hammouti.B, Lamhamdi.A, Mejdoubi. E and Berrabah. M "The Gum Arabic in the southern region of Morocco" Mor. J. Chem. (2015 ) 3 (1): 99-107.

7. Philip. D “ Biosynthesis of $\mathrm{Au}, \mathrm{Ag}$ and $\mathrm{Au}-\mathrm{Ag}$ nanoparticles using edible mushroom extract”. Spectro chim Acta A Mol BiomolSpectrosc . (2009) 73: 374-381.

8. Sinha. T, Ahmaruzzaman. M "Indigenous north eastern India fern mediated fabrication of spherical silver and anisotropic gold nano structured materials and their efficacy for the abatement of perilous organic compounds from waste water-A green approach". RSC Adv6: (2016) 21076-21089.

9. Shankar. SS, Rai. A, Ahmad. A, Sastry. M "Controlling the Optical Properties of Lemongrass Extract Synthesized Gold Nanotriangles and Potential Application in Infrared-Absorbing Optical Coatings”. Chem Mater . (2005) 17: 566-572. 
Preparation Eco-Friend and Characteristic of Gold Nanoparticles by Orchid and Gum Arabic as a Reducing Agent

\section{Dhelal A. Shabeeb, Abdulalah Th. Mohammed and Adawiya J. Haider}

10. Nilsson, L. A “Anthecology of Orchismascula (Orchidaceae)”.Nordic Journal of Botany. (1983) 3: 157-179.

11. Eqbal. D. auqan andAminah Abdullah "Utilization of gum Arabic for industries and human health" American Journal of Applied Sciences . (2013) 10 (10): 1270-1279 .

12. Raj. V , Sreenivasan. K "Selective detection and estimation of C-reactive protein in serum using surface - functionalized gold nano - particles"Analytic Chemica Acta. (2010) 662 . 186-192.

13. Vasenka. J, Manne. S, Giberson. R , Marsh. T and Henderson. E "Colloidal Gold Particles as an Incompressible AFM ImagingStandard for Assessing the Compressibility of Biomolecules," Biophysical Journal . (1993) 65. 992-997.

14. Wang. Z , Mohamed. M , Link. S, El-Sayed. M "Crystallographic facets and shapes of gold nanorods of different aspect ratios"Surface Science. (1999) 440(1): 809-814

15. Chandran. SP, Chaudhary. M, Pasricha. R, Ahmad. A, Sastry. M "Synthesis of gold nanotriangles and silver nanoparticles using Aloe vera plant extract.” Bio technolProg . (2006) 22: 577-583. 